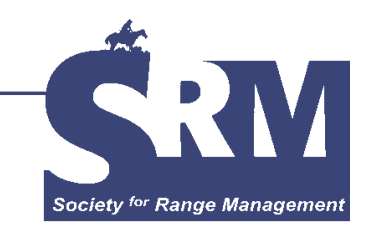

\title{
Water Harvesting From Ranch Roads
}

\section{By Jim Thorpe}

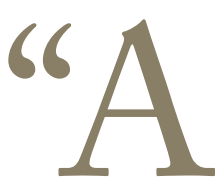

good road lies easy on the land, if it is located on a landform where it can be readily and effectively drained (neither too steep nor too flat); is functional when used as intended (class of vehicle, season and suitable weather conditions); has appropriate drainage features (closely spaced, properly situated and adequately maintained); preserves the natural drainage pattern of the landform; conserves water; does not cause or contribute to accelerated soil loss, lost productivity or water pollution; does not encroach on wetland or riparian areas; and is scenically pleasing."

So writes Bill Zeedyk, building upon the experimental and practical work of a 35-year USFS career, now a full-time consultant ${ }^{\mathrm{i}}$ living near Albuquerque, New Mexico. Perhaps best known for his pioneering work in low-tech and lowcost riparian restoration (see book reviews in the April issue), Bill has also applied his past US Forest Service (USFS) experimental forest experience and innovative tinkering to the design, construction, and maintenance of low-standard rural roads. Low standard? These are not your go-like-hell, seethe-dust-for-miles, John Denver sing-along, country roads, but roads that are "roads" in perhaps name only-not always the best ones for your town visitors to attempt in their lowriding rigs; roads of occasional or infrequent use, low speeds,

'Zeedyk Ecological Consulting, LLC; Restoring Wetland, Riparian, and Upland Habitats; bzcreekz@att.net. Bill first worked with these low standard road approaches in the 1960s in Kentucky's Daniel Boone National Forest and has seen them implemented and adapted to local needs and conditions on more than 300,000 miles of the USFS road web. Bill wishes to recognize the work of Keith Guenther, who concurrently contributed to the development of these approaches. and generally light loads; roads that all too often are rutted, gutted, and gullied so that not only do they ride rough, but they inevitably become conduits of erosion, bleeding needed "irrigation" away from thirsty vegetation. In western arid regions, like New Mexico, where every drop of precipitation needs to be "harvested" for a contribution toward production, any water running down the road to the neighbors is a wasted opportunity!

"A road is not easy on the land if it collects, concentrates, or accelerates surface or subsurface runoff; causes or contributes to soil erosion; impairs or reduces the productivity of adjacent lands or waters; wastes water; unnecessarily intrudes upon key habitats, stream channels, floodplains, wetlands, wet meadows or other sensitive soils; and is aesthetically offensive."

\section{Ranchers Hosting Workshops}

With these 2 paragraphs of succinctly elegant prose as preface, Bill Zeedyk's new road handbook (published in April 2006) encapsulates the basic message of his Ranch Road Workshops held over the past half-decade in conjunction with various sponsoring partners, spearheaded by the Quivira Coalition ${ }^{\mathrm{ii}}$ and including the New Mexico Environment Department, the Bureau of Land Management (BLM), and the US Environmental Protection Agency (EPA). These workshops have been held at a number of ranch locations in New Mexico, including an August 2003 workshop at our ranch near Newkirk, New Mexico (midway in the middle of

\footnotetext{
ii A rangeland conservation-oriented nongovernmental organization (NGO) based in Santa Fe, New Mexico. (http://quiviracoalition.org).
} 
nowhere between Albuquerque, New Mexico, and Amarillo, Texas).

Holding a 2-day workshop at a location 150 miles from primary cities and 35 miles from the nearest interstate motels certainly has its logistical challenges, but the Quivira Coalition is a seasoned producer of such contemporary rangeland events. Close to 50 people turned out, with cowboy hats, ball caps, and pony tails (on both genders) in abundance. Quivira workshops generally offer an optimum combination of outdoor classroom and practical field work and demonstrations, with plenty of time for networking and idea-swapping in-between. Holding a "working" workshop on your ranch can be a good way to get a few things accomplished-the only drawback is that quite a bit of time is spent in exposition and rumination and not quite as much in using the time and equipment that has been made available!

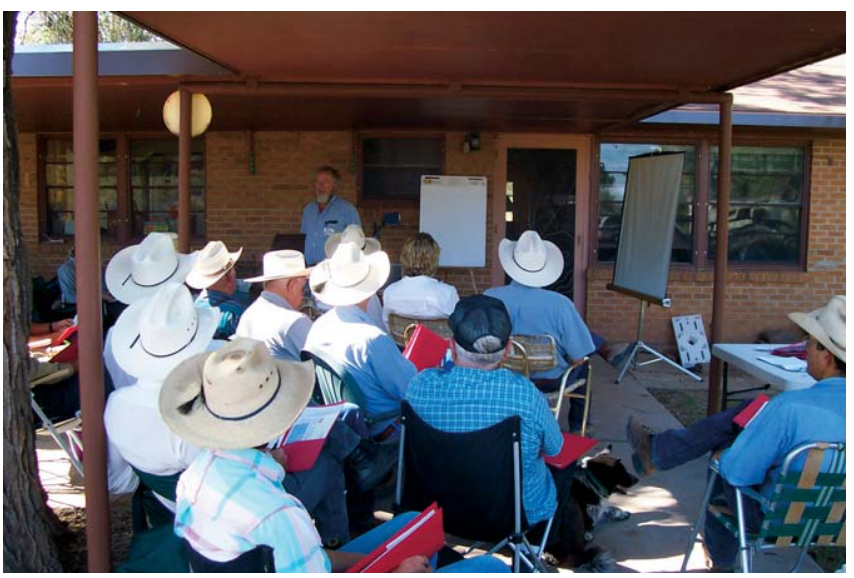

After a few rounds of coffee and how-do-you-dos, Bill sits everyone down for a bit, to shift some paradigms. As important as low-standard ranch roads may be for transportation, getting from here to there, hauling feed and salt, checking livestock, and all the other indispensable chores of windshield ranching, their most important function is to, hopefully in a positive but too often negative way, aid in water management. Rangeland roads are often designed, built, and maintained with speed and least-costs in mind (think of those hurry-up oil and gas outfits!) with too little attention being given to their potential impact on surface runoff patterns and consequent influence on vegetative growth.

Water control structures are often placed (if at all) as haphazard after-thoughts roads with little consideration of where the water goes - and what it does - when it finally leaves the roadbed. The conventional wisdom mind set is that storm water is a nuisance that needs to be shunted aside; the Zeedykian paradigm, in marked contrast, is one of water harvesting. We often notice how vegetation thrives along highway right-of-ways (and may sometimes daydream about using them as paddocks); with a little bit of thoughtful adjustment of management, and a few of Bill's tricks and tips, we can capture much of that same effect for the ranch.
Matching road design to intended purposes (are 20-ft-wide roads always necessary for infrequent travel?), understanding characteristics of soils and available road construction materials, and learning to read the landscape to our advantage (it's not that hard: water tends to run downhill!) are all part of the approach, as well as common sense (if you don't really have to drive on it when it's saturated and muddy-don't!). Keeping storm flows as much as possible within their originating microwatersheds and providing for frequent road drainage ("First chance, best chance, last chance, every chance") will discourage the exponential increase in erosive force often acquired by the accumulation of flowing waters.

After this re-education session, it's time to go out in the field to look at some situations. Sometimes a road may not be necessary or may not necessarily need to be where it is. Near our ranch headquarters are several small trap pastures handy for holding cattle before shipping or other workday events, as well as one we use for the first-calving heifers after calving; we drive in that one most every day to check the pairs and feed them "cake" (supplemental protein cubes). This

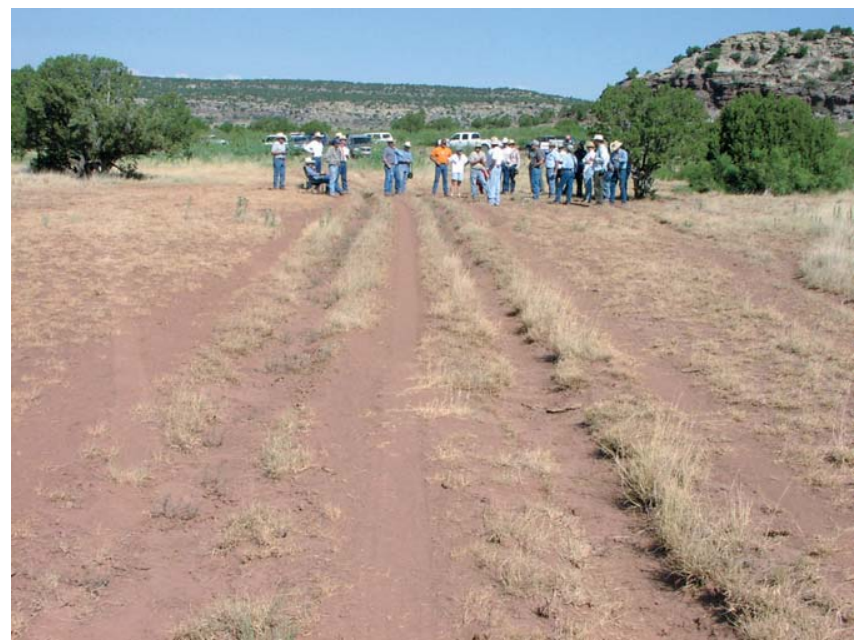

Quivira Road Workshop, August 2003, viewing runaway ruts.

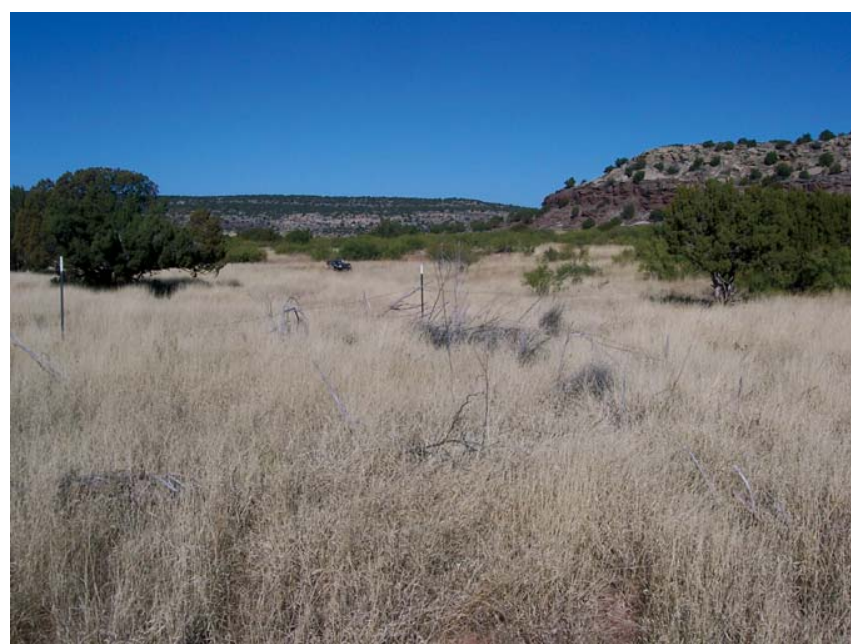

Same view, October 2006. 
100 -acre pasture is a long, narrow valley shaped like a giant zucchini, running uphill through a galleta-dominated swale before reaching blue-black gramma, sandy-loam uplands that abruptly end at sandstone rimrock. Not surprisingly, the main 2-track "road," with all our driving back and forth and the coming and going of cattle to water (at the lower end), gets beat down and torn up considerably. We explained to the workshop our concern that, between our feed truck and the trailing cattle, our run-away ruts were soon going to become incised arroyos.

The workshop group ruminated on various suggestions, such as whether management could be flexible enough to change the location of the feed and access road away from the potentially productive swale (and somehow snake it through the mesquite thorn-infested, tire-eating side slopes), whether the grazing management could be altered to provide adequate rest and recovery time, whether cattle traffic patterns could be (inexpensively) altered, whether reseeding was necessary, and whether we shouldn't just regard the feed zone as a no-bigdeal sacrifice area.

The treatment decided upon was to route a new feed trail that stayed out of the bottom (and, after trimming, hacking, and spot-applications of herbicide on opposing mesquites, serpentine along the side slopes), use the idling nearby dozer to rip a herringbone pattern of draw-away ditchlets across the old route, lay cut juniper boughs across the bare areas to create protected microsites, and install temporary 1-wire drift fences to encourage cattle trailing at angles appropriate for dispersing and spreading runoff. Not much to it, really. Three years later (without any further treatments), we now often feed cattle in this area to encourage a bit of animal impact on the thick stands of self-reclaimed galleta and alkali sacaton.

\section{Variations on an Old Theme}

Of course, we just can't undo and unroad our whole transportation network (despite the pleadings of all the roadless visionaries). For the roads we do need (and use!), the workshop addressed the design of that most common of ranchroad drainage structures, the water bar, or as it is often known in the southwest, the "Thank You, Mam!" (I suspect that the near whiplash, tipping effect on the hat and head and neck, sometimes unexpectedly compelled by abrupt contact with these devilish rangeland speed bumps, may be the slightly satirical derivation of the moniker "Thank You, Mam").

As we were now in the 21st century, we needed an updated name as well as design. Water bars may now be going the way of the 19th century buggy whip; their replacement is the rolling dip. What's in a name? Well there are some subtle differences of angle and approach, which would require a couple more pages (much more than Frasier has allotted me here, and
I'm not even discussing the challenges of culverts!). Suffice it to say that a rolling dip is a vast evolutionary improvement over the traditional water bar, requires less frequent maintenance (actually, they are often self-maintaining), and provides a much smoother ride (especially when they are properly scaled, lengthwise, for the longest vehicles expected, such as cattle-trucks or crewcabs bumper-pulling featherlites).

Installing and maintaining these rolling dips and other contemporary designs does require some retraining of road equipment operators, especially those employed by local government road departments. Indeed, it is essential because a "helpful" operator can often undo, in a few minutes, hours of careful design and installation. Bill has begun working with watershed groups and county road departments in New Mexico (Colfax) and Arizona (Pima). The county road departments are attracted by the prospect of potentially lower maintenance costs (they are a bit spooked, however, that these unconventional approaches might have unforeseen liability repercussions). By getting these techniques validated and incorporated into conventional practice, the multiplier effect, in terms of the ecological and social benefits of increased forage production and watershed integrity, could be substantial. Overcoming tradition and past practice continues to be a great challenge in this as in other rangeland innovations - this author believes that all of us, as individuals and as a professional society, have an important role in developing support and validation for such rangeland innovations of merit.

All of these, the basic principles, the new paradigms, the rolling-dip details, and more (including a new, somewhat oxymoronic invention, the flat-land drain, first conceived and constructed during this ranch workshop) are in the ranch roads workbook - and it's free (plus shipping) for the asking via quiviracoalition.org! (It's amazing what a retired federal employee, teamed up with a rangeland-oriented NGO and numerous willing landowners, can accomplish outside of the boxes of protocol, tradition, and turf.)

A final tip from Bill: The best time to read the roadscape is in the rain. Get out there, and see how the water flows, where it's going, and where it might be better directed. Take that decorative item (otherwise known as a shovel) out from its prominent place on the pick-up headache rack, and, like any good irrigator, turn that water where it needs to go to grow a little more grass. Just be careful it doesn't become a lightning rod!

Author is a member of the New Mexico section ranching at jtlandandcattle.com, Newkirk, NM 88431, jimthorpe@ wildblue.net 